\title{
Description Of The Development Of Children Age 4-5 Years In TK Pelangi
}

\author{
Wahyudi ${ }^{1}$, Amirullah $^{2 *}$, Haerani $^{3}$ \\ ${ }^{1}$ Nursing Student, Stikes Panrita Husada Bulukumba, Indonesia \\ ${ }^{2,3}$ Department of Nursing Stikes Panrita Husada Bulukumba, Indonesia
}

Corresponding author: Amirullah

Email: amirullahulla@gmail.com

\begin{abstract}
There are several factors that can affect children's development that is not fulfilled, namely, poverty, malnutrition, high levels of family and environmental stress that cause children to be exposed to violence, abuse, and lack of attention and learning opportunities. Children who do not have enough learning time or even do not have the same opportunity to learn can affect their motor development, for example, the brain damage that does not support children to develop motor skills. Lack of research that discusses the developmental picture in children aged 4-5 years, so researchers are interested in doing this research. The purpose of this study was to determine the development of children aged 4-5 years in Pelangi Kindergarten, Anrang Village, Bonto Masunggu Hamlet, Bulukumba Regency in 2020. The method used in this research is descriptive design, which aims to get a picture of the development of children aged 4-5 years in Kindergarten Pelangi, Anrang Village, Kec. Rilau Ale. The population in this study was 31 respondents and the sample size was 31 child respondents in Kindergarten Pelangi, Anrang Village, Kec. Rilau ale. The results obtained are that the researcher found the results of 31 respondents with the highest motor development results in accordance with the number of 21 respondents $(67.7 \%)$, while with the lowest development there were deviations with respondent $3(9.7 \%)$. The conclusion and suggestion are that there is a description of the development of children in Kindergarten Pelangi, Anrang Village, Kec. Rilau Ale
\end{abstract}

\section{Key Words: Development, Motor Skills, Children}




\section{PENDAHULUAN}

Perkembangan anak tidak terpenuhi dipengaruhi oleh beberapa faktor yang dapat mempengaruhi perkembangan anak tidak terpenuhi yakni, kemiskinan, kekurangan gizi, tingginya tingkat stress keluarga dan lingkungan yang menyebabkan anak rentang terhadap kekerasan, pelecehan, serta kurangnya perhatian dan kesempatan belajar. Anak yang waktu belajarnya kurang atau bahkan tidak memiliki kesempatan sama seklai untuk belajar dapat mempengaruhi perkembangan motorik anak, misalnya kerusakan otak yang tidak mendukung anak untuk mengembangkan kemampuan motoriknya.

Dilihat dari data (WHO, 2013) dalam (Susanti, 2014), mengutip bahwa 5-25\% anak balita mengalami gangguan motorik halus. Untuk mengetahui perkembangan motorik anak Depkes RI melakukan skrining perkembangan di 30 provinsi di Indonesia yang mengatakan bahwa 45,12\% anak mengalami gangguan perkembangan, dari hasil penelitian yang di lakukan di Jawa Barat prevalensi anak yang mengalami gangguan perkembangan sejumlah $30 \%$ anak, dan $80 \%$ di pengaruhi oleh kurangnya pemberian stimulasi dini pada anak.

Berdasarkan data (Statistik, 2016) pendidikan anak usia dini pada tahun2016 sampai 2017 jumlah lembaga pendidikan anak usia dini di Sulawesi Selatan sebanyak 2.277 lembaga, dengan peserta didik sebanyak 198.277 orang yang di didik oleh 4.910 orang pendidik. Dan data pada tahun 2018 sampai 2019 jumlah lembaga PAUD di Sulawesi Selatan sebanyak 4.290 lembaga dengan jumlah peserta didik 163.885 orang yang di didik oleh 15.487 pendidik. Jika di lihat dari jumlah pendidikan anak usia dini di Sulawesi Selatan kurangnya pemberian stimulasi dini pada anak di pengaruhi oleh data (Depkes, 2012), bahwa 16\% balita mengalami gangguan motorik kasar dan motorik halus di Indonesia. Dan pada tahun 2013, 35,4\% mengalami penyimpangan terhadap perkembangan motorik serta penyimpangan mental emosional.

Dampak dari keterlambatan perkembangan motorik anak dapat disebabkan oleh kurangnya rangsangan dan stimulasi, tumbuh kembang optimal dapat tercapai apabila intraksi antara anak dan orang tua, terutama stimulasi sangat bermanfaat bagi proses perkambangan anak secara keseluruhan. untuk meningkatkan perkembangan motorik halus anak, setiap anak perlu mendapat stimulasi rutin sedini mungkin dan terus-menerus pada setiap kesempatan. Kurangnya stimulasi dapat menyebabkan penyimpangan tumbuh kembang anak (Utami, 2016). 


\section{BAHAN DAN METODE}

\section{Desain Penelitian}

Adapun desain yang digunakan pada penelitian ini adalah desain deskriktif, yang bertujuan untuk mendapatkan gambaran tingkat perkembangan anak usia 4-5 tahun di Tk Pelangi Desa Anrang Kec. Rilau ale.

\section{Populasi Dan Sampel}

Populasi merupakan wilayah generalisasi yang terdiri atas objek atau subjek yang mempunyai kualitas dan karakteristik tertentu yang telah di tetapkan peneliti untuk di pelajari dan kemudian di tarik kesimpulanya. (Sugiyono, 2014 ). Populasi yang tersedia dalam penelitian ini ialah anak yang usia 4-5 tahun di TK Pelangi sebanyak 31 orang di Dusun Bonto Masunggu Desa Anrang. Sampel merupakan bagian dari keseluruhan jumlah dan karakteristik yang dimiliki oleh populasi yang dianggap telah mewakili keseluruhan populasi (Sugiyono, 2014 ). Besar sampel pada penelitian ini sebanyak 31 orang di Dusun Bonto Masungg Desa Anrang. Pada penelitian ini teknik sampling yang di gunakan adalah total sampling yang akan di berlakukan untuk populasi, di mana jumlah keseluruhan populasi yang kemudian dijadikan sampel yakni 31 responden.

\section{Instrumen Pengumpulan Data}

Instrument dalam penelitian ini adalah kuesioner (angket).

\section{Analisa Data}

Data dianalisis berdasarkan skala ukur dan tujuan penelitian dengan menggunakan perangkat lunak program komputerisasi. Data dianalisis secara Univariat, Analisis dilakukan untuk melihat proporsi.

\section{HASIL}

Berdasarkan tabel 1 menunjukkan bahwa reponden jenis kelamin laki-laki lebih banyak yaitu 16 responden (51.6\%) dan untuk responden perempuan sebanyak 15responden( $48.8 \%$ ). Untuk usia reponden dengan usia 4 tahun sebanyak 9 responden $(29.0 \%)$, dan untuk usia 5 tahun sebanyak 22 responden (71.0\%). 
Tabel 1.Distribusi karakteristik responden anak usia 4-5 tahun di Tk Pelangi

\begin{tabular}{lcc} 
Karakteristik responden & Frekuensi $(\boldsymbol{F})$ & Presentase $(\%)$ \\
\hline Jenis kelamin & 16 & $51.6 \%$ \\
Laki-laki & 15 & $48.8 \%$ \\
Perempuan & & \\
Usia & 9 & $29.0 \%$ \\
4 tahun & 22 & $71.0 \%$ \\
5 tahun & $\mathbf{3 1}$ & \\
\hline Total & $\mathbf{1 0 0 , 0 0}$ \\
\hline
\end{tabular}

Berdasarkan tabel 2 dari 31 responden (100\%) didapatkan hasil perkambangan tertinggi sesuai dengan jumlah 21 responden (67.7\%), sedangkan dengan perkembangan yang paling rendah ada penyimpangan dengan responden $3(9.7 \%)$.

Tabel 2. Distribusi frekuensi prekuensi perkembangan anak usia dini

\begin{tabular}{lcc}
\hline Depresi & Frekuensi $(\boldsymbol{F})$ & Presentase \% \\
\hline Ada penyimpangan & 3 & $9.7 \%$ \\
Meragukan & 7 & $22.6 \%$ \\
Sesuai & 21 & $67.7 \% \%$ \\
\hline Total & $\mathbf{3 1}$ & $\mathbf{1 0 0 , 0}$ \\
\hline
\end{tabular}

\section{PEMBAHASAN}

Berdasarkan hasil penelitian yang dilakukan di Tk Pelangi Desa Anrang Kec. Rilau ale. Dapat diketahui bahwa perkembangan anak usia 4-5 tahun bervariasi mulai dari perkembangan meragukan hingga terdapat penyimpangan. Untuk proporsi tertinggi yaitu sesuai, sedangkan yang paling rendah yaitu terdapat penyimpangan. Pada penelitian ini ditemukan adanya anak dengan status perkembangan yang masi meragukan dan ada penyimpangan. Dapat dilihat hasil crosstab untuk proporsi usia tertinggi yang terdapat penyimpangan yaitu usia 4 tahun dengan hasil crosstab (22.2\%) dan untuk jenis kelamin proporsi tertinggi yang meragukan yaitu perempuan dengan jumlah (26.7\%). Dari hasil pedoman pelaksanaan KPSP (Kuesioner Pra Skrining Perkembangan) yang digunakan berdasarkan sesuai usia anak bagi balita yang memilki status perkembangan meragukan, upaya yang harus dilakukan yaitu memberikan petunjuk pada ibu untuk melakukan stimulasi perkembangan pada anak lebih sering lagi dan 
mengasah percaya diri pada anak sehingga anak tersebut mampu bersosialisasi dengan teman sebayanya.

Temuan ini juga didukung oleh (yanuarita, 2014) yang mengemukakan bahwa Perkembangan merupakan proses tumbuh kembang yang pada dasarnya perkembangan sejalan dengan kematangan saraf dan otak yang tertuju pada gerak tumbuh anak sebagai system dalam tubuh yang dapat terkontrol oleh otak. Beberapa faktor juga dapat mempengaruhi perkembangan menurut (Marmi, 2015), salah satu diantaranya yaitu faktor lingkungan. Dimana lingkungan merupakan sumber belajar yang sangat bermanfaat bagi anak. Lingkungan pembelajaran berupa lingkungan fisik dan non fisik. Lingkungan fisik berupa penataan ruangan, penataan alat main, benda-benda yang ada di sekitar anak, sedangkan lingkungan non fisik berupa kebiasaan orang-orang sekitar, suasana belajar (keramahan pendidik, pendidik yang siap membantu) dan intraksi guru. Lingkungan juga dapat mempengaruhi perkembangan bahasa anak dimana merupakan tahap perkembangan kemampuan untuk memperoleh dan mempergunakan simbol-simbol verbal atau non-verbal yang didapat dari lingkungan anak.

Kemampuan sosialisasi yang dimiliki anak dipengaruhi oleh faktor lingkungan, terutama oleh keluarga, yaitu peran dan keterlibatan orang tua yang tercermin di dalam pelaksanaan pola asuh. Menurut (Ekowati, 2016), bila anak mendapat stimulasi, penerimaan, dan kehangatan dari ayah, ibu dan nenek atau kakek akan berpengaruh positif bagi perkembangan sosial anak, jika lingkungan rumah secara keseluruhan memupuk dan mengembangkan sikap sosial yang baik, kemungkinan besar akan menjadi pribadi yang sosial yang akan mempengaruhi anak dalam kemampuan sosialisasi baik dalam keluarga maupun di luar keluarga (masyarakat). Aspek kemampuan penyesuaian sosial anak yang diartikan sebagai keberhasilan seseorang untuk menyesuaikan diri, tingkah laku, sikap, dan nilainya sesuai dengan tuntutan kelompok. Penyesuaian sosial menjadi sulit bila anak tidak menyetujui cita-cita kelompok. Anak akan berhasil dalam penyesuaian sosial dengan baik dan dapat diterima sebagai anggota kelompok sosial ketika anak menyukai orang dan aktivitas sosialnya. Perkembangan motorik adalah aspek terpenting dalam mendorong perkembangan, selain di perlukan bimbingan perlu di perhatikan kebutuhan anak yang tidak menutup kemungkinan memiliki kebutuhan dan minat sama. Anak yang cenderung motoriknya rendah dalam bergerak akan lebih memilih aktivitas yang tidak berkaitan dengan fisik, padahal aktivitas fisik sangat berpengaruh pada kemampuan anak dalam berfikir serta berinteraksi terhadap lingkungan sosial. 
Perkembangan motorik kasar merupakan gerakan tubuh yang menggunakan otot-otot besar atau sebagian besar seluruh anggota tubuh yang dipengaruhi oleh kematangan anak itu sendiri. Contohnya kemampuan duduk, menendang, berlari, naik-turun tangga dan sebagainya. Anak yang mencapai perkembangan motorik kasar yang normal bahkan lebih/ advanced maka anak itu memiliki keyakinan dan percaya diri bahwa dirinya pasti bisa melakukan hal tersebut. Sebaliknya jika anak yang perkembangan motorik kasarnya mengalami keterlambatan atau delay dan caution karena faktor anak tersebut yang merasa takut dan tidak yakin dengan apa yang dilakukan. Sedangkan Motorik halus adalah gerakan yang menggunakan otot-otot halus atau sebagian anggota tubuh tertentu, yang dipengaruhi oleh kesempatan untuk belajar dan berlatih. Misalnya, kemampuan memindahkan benda dari tangan, mencoret-coret, menyusun balok, menggunting, menulis dan sebagainya. Sedangkan perkembangan motorik halus pada masa ini anak telah mampu mengkoordinasikan gerakan visual motorik, seperti mengkoordinasikan gerakan mata dengan tangan, lengan dan tubuh secara bersamaan antara lain dapat dilihat pada waktu anak menulis atau menggambar. Dengan demikian anak-anak harus lebih sering dilatih dan diperhatikan perkembangan motorik halusnya, karena kemampuan tersebut sangat penting bagi anak untuk lebih terampil dan kreatif. Anak yang perkembangan motorik halusnya normal bahkan lebih/ advanced, anak itu akan merasa senang dan percaya diri bahwa dirinya bisa untuk melakukan motorik halus seperti menggambar dan melukis. Sedangkan anak yang perkembangan motorik halusnya mengalami keterlambatan atau delay dan caution pada anak disebabkan karena faktor ketidak tahuan anak dengan apa yang harus dilakukan (Zainal Munir, 2019).

Perkembangan lebih mengarah kepada kualitas jadi perkembangan dapat diartikan sebagai akibat dari perubahan kematangan dan kesiapan fisik yang memiliki potensi untuk melakukan suatu aktivitas, sehingga individu telah mempunyai suatu pengalaman (Dariyo, 2007). Studi ini didukung pada penelitian yang dilakukan oleh (Sulistyawati, 2016), mengatakan bahwa berdasarkan hasil penelitian didapatkan data bahwa responden dengan PAUD dengan hasil sesuai sebanyak $68,7 \%$ lebih banyak dibandingkan dengan hasil meragukan atau penyimpangan sebesar 40\%. Terdapat kesamaan dengan penelitian yang dilakukan oleh (Nirmawati, 2018), dimana hasil yang di dapatkan dari 35 responden yang mengikuti PAUD, yang mengalami perkembangan motorik sebanyak 29 responden $(82,9 \%)$ sedangkan yang tidak berkembang sebanyak 6 reponden $(17,1 \%)$. 
Peneliti berasumsi bahwa perkembangan anak di Tk Pelangi sebagian besar sudah berkembang karena pendidikan anak usia dini memiliki tempat yang kondusif, dan alat permainan yang lengkap serta mendapatkan stimulasi yang lebih terarah yang akan berdampak baik bagi perkembangannya. Akan tetapi masi terdapat beberapa anak yang perkembangan motoriknya belum berkembang. Hal ini disebabkan karena kurang percaya diri pada anak sehingga anak tersebut tidak mampu bersosialisasi dengan teman sebayanya dan anak tampak ragu-ragu dalam melakukan gerakan akibat trauma atau takut untuk bergerak.

\section{KESIMPULAN DAN SARAN}

Proporsi perkambangan motorik tertinggi sesuai dengan jumlah 23 responden (74.2\%), sedangkan dengan perkembangan motorik yang paling rendah ada penyimpangan dengan responden 3 (9.7\%). Distribusi jumlah responden berdasarkan perkembangan motorik yang ada penyimpangan dengan jumlah 3 responden (9.7\%). Di harapakan institusi terkait dari penelitian ini dapat memberi masukan dan sebagai dasar untuk melakukan penelitian lebih lanjut yang berkaitan dengan perkembangan anak terutama tentang pelaksanaan program PAUD.

\section{DAFTAR PUSTAKA}

ANNIES LISTYOWATI, D. A. W. 2017. kompendium pendidikan anak usia dini, Depok, PRENADAMEDIA GROUP.

DARIYO, A. (ed.) 2007. Psikologi Perkembangan Anak Tiga Tahun Pertama, Bandung.

DARMA, K. K. 2017. metodologi penelitian keperawatan, jakarta, Trans Info Media.

DEPKES, D. K. R. I. 2012.

EKOWATI, M. 2016. Perbedaan kemasakan sosial antara anak prasekolah ditinjau dari keikutsertaan ibu dalam program bina keluarga balita di Kecamatan Mlati Kabupaten Sleman Yogyakarta, .

ERNI YUNITA, A. H. A. 2018. pengaruh layanan bimbingan kelompok terhadap keterampilan motorik anak usia dini. jurnal copasta, I.

HIDAYAT, A. A. A. 2017. metodologi penelitian keperawatan dan kesehatan, jakatra, salemba medika. 
MARMI, S. (ed.) 2015. Asuhan neonatus, bayi, balita, dan Anak Pra Skolah., jakarta pusat: pustaka belajar.

MEITA, D. 2016. kuesioner praskrining perkembangan ( Ksps) anak. sari pediarti, 8.

NIRMAWATI 2018. Hubungan Anak Yang Mengikuti Pendidikan Anak Usia Dini (PAUD) Dengan Perkembangan Motorik Di Tk Artika.

NOVAN, W. A. 2014. psikologi perkembangan anak usia dini panduan bagi orang tua dan pendidik PAUD dalam memahami serta mendidik Anak usia dini, Yogyakarta, Gava Media.

ROMI CENDRA, N. G., TAKTON PARULIAN,ALFICANDRA,LENI APRIANI 2018. pelatihan metode perkembangan motorik kasar anak usia dini pada guru paud. jurna pengabdian masyarakat, II.

STATISTIK, S. P. A. U. D. 2016.

SULISTYAWATI, A. 2016. dukungan pendidikan anak usia dini (PAUD) terhadap tumbuh kembang anak.

SUSANTI, R. A. L. 2014. faktor yang mempengaruhi tigkat pengetahuan ibu terhadap perkembangan motorik kasar dan motorik halus pada balita usia 3-5 tahun di PAUD Aladawiyah sukatani bekasi.

SUSANTO 2011. perkembangan anak usia dini, jakarta, kencana medika.

SUYANTO, S. D. 2014. metodologi penelitian epidemilogi bidang kedokteran dan kesehatan. yogyakarta: Bursa ilmu.

SYAHDA 2014. Hubungan Anak Mengikuti Pendidikan Usia Dini (PAUD) Dengan Perkembangan Motorik Anak Pra Skolah Yang Masuk Sd Di Desa Glora Kecamatan Bagan Sinembah Kabupaten Rokan Hilir. kebidanan STIKES tuanku tambusai riau. 
UNICEF, U. N. C. S. F. 2017.

UTAMI, R. B. 2016. pengaruh stimulasi motorik terhadap perkembangan motorik halus anak usia 4-5 tahun di taman kanak-kanak pertiwi tripan brebek nganjuk. keperawatan.

WAHYU NANDA EKA SAPUTRA, I. S. 2016. perkembangan motorik halus anak usia 3-4 tahun di kelompok bermain cendikia kids scool madiun dan implikasinya pada layanan konseling. jurnal care, III.

WHO, W. H. O. 2013.

YANUARITA, F. A. 2014. rahasia otak dan kecerdasan anak, jogjakarta, teranova books.

ZAINAL MUNIR, Y., HELPY VIRANA 2019. Hubungan Pola Asuh Orang Tua dalam Menstimulasi Perkembangan Motorik Kasar dan Halus Usia Pra Sekolah. Jurnal Keperawatan Profesional (JKP). 